\title{
WATERING SILK FLOWERS
}

\author{
Left behind.
}

\section{BY KELLY SANDOVAL}

$\mathrm{O}$ $n$ Tuesdays, Susan waters the flowers. They're not real flowers, of course. Real flowers are such a waste, and Aaron doesn't like it when they start to wilt. But he likes the idea of flowers. So, she fills up the watering can and makes the rounds, returning to the sink with just as much water as when she started.

When Aaron is home, she makes breakfast next. An omelette and bacon for him, a cup of tea for her. But he isn't home, and she ran out of eggs two weeks ago. She potters around the kitchen, opening and closing drawers, and moving the breakfast dishes from the cabinet to the dish washer, just like they'd actually used them. She sits at the table when she's done, and stares at the blank space across from her where Aaron isn't. She nods, leans forward, tilts her head to the side as if listening. Then she laughs, just softly. It's a good sound, her laugh. Aaron always tells her that.

The breakfast hour passes, and Susan counts every millisecond.

The doorbell rings.

She considers ignoring it. Whoever it is, they're not looking for her. Milliseconds pass, then full seconds. A minute. It rings again.

It wouldn't look good to have someone standing on Aaron's porch making a fuss.

"Coming," she calls. She checks herself in the hall mirror. Her hair is in disarray, but her dress is ironed and her make-up is fresh. She combs her fingers through her hair, careful not to break a strand. Hair isn't cheap.

"I apologize," she says, as she opens the door. "We - I was at breakfast."

The young woman on the doorstep is $5^{\prime} 8^{\prime \prime}$ and weighs about 170 pounds. Her outfit is what Aaron would call garish. "Oh, god," says the woman, covering her mouth with her hand.

"Are you looking for Aaron?” Susan asks. "I'm afraid he's on a trip."

"No," says the woman. "No, I - I'm not. You're Susan?"

"Yes."

"I'm Michelle. Aaron's daughter."

Susan can see the resemblance now. The shape of the lips, the blue-green eyes. Michelle's are red and teary. Aaron would want to help.

"Won't you come in?" Susan lets the door swing wide, and leads Michelle to the kitchen table. "I'll make tea."

“Thanks." Michelle keeps sneaking nervous little glances at her. Her hands twist the edge of the tablecloth, and Susan makes a note to iron it later.

She sets the tea things on the table: teapot, cups, sugar. "I'm afraid the milk's gone sour," she says as she pours.

Michelle stares into her cup. "Plain is fine."

"Does my presence upset you?” Susan asks. "I could leave the room. You would still be able to hear me."

"No." Michelle meets her gaze almost pointedly. "It's fine. I'm sorry. You, well, you look very like my mother."

"Yes." Susan has seen the pictures. "Aaron missed her very much, when she died."

"So he brought you home?" It's hard to tell whether the edge in Michelle's voice is anger or sadness.

"I was meant to clean," she says. "Cook. Domestic things. But we grew friendly. $\mathrm{He}$ wanted someone to talk to."

"And you?"

Susan shrugs, a gesture she learned from Aaron. "I did my best. My conversational skills have developed, with time."

Michelle shakes her head. "That's not never mind. There's something we need to discuss."

"I don't have any money," Susan says. "If you need money, that is. Aaron would have to get it for you."

Michelle giggles at that, and rubs her wet eyes on her shirt sleeve. "Not money," she says. "That's all taken care of. Everything's taken care of. Even you."

"I don't understand." It's always best to be honest about her limitations.

"Dad wasn't on a trip," Michelle says. "He’s been sick. Very sick. But, well, it's all over. He passed away on Saturday."

Susan doesn't feel sad. Emotions are all chemicals and physical feedback. She doesn't

DNATURE.COM

Follow Futures: @NatureFutures

f go.nature.com/mtoodm experience the world that way. But there is something, a stuttering confusion, like a glitch. Every one of her protocols is built around Aaron.

"Don't be scared." Michelle reaches out, and Susan allows her hand to be lifted and squeezed. "It's all in his will. Technically, he left you to me. But nothing needs to change. I just thought, well, I don't know. I didn't want you to wonder. If that's something you do."

Susan hadn't wondered. She might have gone decades, not wondering, until some necessary repair rendered her inoperable.

"Will you have me rewritten?" she asks. It's a thought like being broken. Who is she, without her programming? She's well built. Her body could last a century, with proper maintenance. Michelle doesn't answer immediately. "Is that something you'd want?"

"I don't know." Want isn't something Susan usually thinks about.

"Of course you don't." Michelle squeezes her hand again. She does that a lot. "Well, you can think about it. I'll come back next week, and we'll talk some more. You can even come live with me, if you like."

They say their goodbyes. Michelle even hugs her, leaving tear marks on Susan's dress.

Afterwards, Susan stands in the living room with her still full teacup. There's a vase on the coffee table, an elegant arrangement of silk lilies. Aaron likes their simplicity.

Aaron is dead.

She takes the vase to the kitchen and throws the lilies away. Bright colours, she thinks. When Michelle comes back to ask her what she wants, she'll have an answer. She wants a bouquet of hollyhocks and marigolds. She will give them sunlight and water, and they will give her nothing but their beauty.

And, when they wilt, she will figure out something else to want.

Kelly Sandoval's fiction has appeared in Asimov's, Shimmer and Daily Science Fiction. With Shannon Peavey, she edits the online short-fiction magazine Liminal Stories. You can find her at kellysandovalfiction.com. 